\title{
Assessing the role of local institutions in participatory development: The case of Khwee and Sehunong settlements in Botswana
}

\begin{tabular}{|c|c|}
\hline \multicolumn{2}{|c|}{$\begin{array}{l}\text { Authors: } \\
\text { Keneilwe Molosi-France }{ }^{1} \\
\text { Kenneth Dipholo }\end{array}$} \\
\hline \multicolumn{2}{|c|}{$\begin{array}{l}\text { Affiliations: } \\
{ }^{1} \text { Department of Adult } \\
\text { Education, Faculty of } \\
\text { Education, University of } \\
\text { Botswana, Botswana }\end{array}$} \\
\hline \multicolumn{2}{|c|}{$\begin{array}{l}\text { Corresponding author: } \\
\text { Kenneth Dipholo, } \\
\text { dipholok@mopipi.ub.bw }\end{array}$} \\
\hline \multicolumn{2}{|c|}{$\begin{array}{l}\text { Dates: } \\
\text { Received: } 21 \text { June } 2017 \\
\text { Accepted: } 08 \text { Aug. } 2017 \\
\text { Published: } 02 \text { Oct. } 2017\end{array}$} \\
\hline \multicolumn{2}{|c|}{$\begin{array}{l}\text { How to cite this article: } \\
\text { Molosi-France, K. \& Dipholo, } \\
\text { K., 2017, 'Assessing the role } \\
\text { of local institutions in } \\
\text { participatory development: } \\
\text { The case of Khwee and } \\
\text { Sehunong settlements in } \\
\text { Botswana', Africa's Public } \\
\text { Service Delivery and } \\
\text { Performance Review 5(1), } \\
\text { a181. https://doi.org/ } \\
\text { 10.4102/apsdpr.v5i1.181 }\end{array}$} \\
\hline \multicolumn{2}{|c|}{$\begin{array}{l}\text { Copyright: } \\
\text { ( ) 2017. The Authors. } \\
\text { Licensee: AOSIS. This wo } \\
\text { is licensed under the } \\
\text { Creative Commons } \\
\text { Attribution License. }\end{array}$} \\
\hline \multicolumn{2}{|l|}{ Read online: } \\
\hline 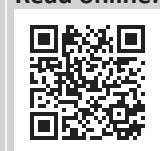 & $\begin{array}{l}\text { Scan this QR } \\
\text { code with your } \\
\text { smart phone or } \\
\text { mobile device } \\
\text { to read online. }\end{array}$ \\
\hline
\end{tabular}

\begin{abstract}
Many governments in Africa give priority to rural development mainly because a significant proportion of their populations live in the rural areas where poverty is severe. Thus, one of the goals of rural development is to address the problem of poverty in the rural areas with an emphasis on promoting participation of people in decisions that affect them. The Village Development Committee (VDC) is a village-level institution that is responsible for ensuring that the community actively participates in the development process in order to promote grassroot development. Essentially, VDCs have been established to offer a forum for community engagement in the processes that concern their development with a view to promote a sense of responsibility, commitment and ownership by the community. This discussion is informed by a qualitative study that used semi-structured interviews to gather data. Two findings pertaining to the weak role of the VDC and unequal power relations are seen to be hindering community participation. As such, this paper argues that VDCs in Khwee and Sehunong settlements do not serve their intended purpose of engaging the community as other stakeholders pay lip service to community participation, hence not fully involving the VDC. The paper recommends that the Government of Botswana as the main stakeholder in national development, including the development of San communities, should commit to genuine community participation, while on the other hand the San should be empowered so that they can embrace and demand to be involved in their own development.
\end{abstract}

\section{Introduction}

People's participation in government and development activities has taken centre stage in development discourse particularly in the African context as countries struggle to find an appropriate development model. The democratisation process has also provided the impetus for the changing focus of development theories and practice. Consequently, local government has been given a pivotal role in development which is why Botswana's decentralisation is justified in terms of democracy and development (Dipholo \& Mothusi 2005), essentially to ensure that the country's democratic tradition and development philosophy is sustained and improved through accountability and the extension of genuine democratic processes to local government or government at the local level (Reddy 1999). Thus, decentralisation is intended to promote greater involvement of citizens and civil society in decision-making with a view to facilitating sustainable locally induced development (Sharma 1999).

The goal of decentralisation is thus to ensure that decisions about improving the quality of life of people living in the rural areas are taken in ways that achieve increased accountability and citizen participation on the one hand and more efficient administrative performance on the other hand. In effect, the Revised National Policy for Rural Development (Republic of Botswana 2002:8) commits the Government of Botswana to an improved institutional and implementation framework for rural development that includes greater decentralisation. In this context, decentralisation sought to transfer decision-making powers from the centre to local government institutions to stimulate citizen participation as well as to promote greater accountability because local governments are closer to the people. Rural development is therefore concerned with strengthening local level institutions such as Village Development Committees (VDCs), which have a responsibility for planning and implementation of village development programmes and projects.

However, this paper argues that VDCs in Khwee and Sehunong settlements do not effectively serve their intended purpose because the central government as the main financer of national development projects including community projects makes the final decisions on development 
matters which more often than not disregard development projects that have been identified by VDCs. It should be noted that development projects that have been identified by VDCs do in fact reflect the felt needs of the villagers and when the central government disregards such projects, it directly excludes the people from decision-making. This is largely because of the existing power relations that place communities, especially minorities, in an inferior position relative to the central government. The introductory part of the paper contextualises decentralisation as a strategy for achieving rural development through citizen participation. The theoretical framework of the paper discusses the theory underpinning this discussion, followed by a discussion on VDCs villagelevel structures established to operationalise citizen participation in decision-making. The next section discusses the methodology adopted by the study followed by a findings and discussion section. The conclusion will provide a summary of the main issues discussed in the paper.

\section{Who are the San?}

This section seeks to help the readers have a picture of who the San are in order that they appreciate some of the unequal power relations issues being discussed. According to the historical accounts, the San were the first people to inhabit what is now called Botswana (Wagner 2006). However, while they are generally considered as an indigenous group, the Government of Botswana refutes this status on the basis that all Batswana are indigenous except for those who are Batswana by naturalisation (Government of Botswana 1993:29). The government further argues that giving the San an indigenous status will bring divisiveness in the society as this may give rise to negative even racist reactions from other segments of the society (Saugestad 2001). In reaction to this, Ditshwanelo (2006) negates this claim as just 'formal equality' which is based on seeing everyone in the same form or image while treating people equally does not make people equal in terms of results.

Relations of inequality between the Tswana-speaking groups and the San can be evidenced by the complex unequally perceived statuses of different ethnic groups, where some are regarded as 'inferior' and others 'superior' (Datta \& Murray 1989). In Botswana, differing ethnic status is supported by the Constitution which only recognises eight Tswanaspeaking tribes despite there being approximately 34 ethnic groups (Nyathi-Ramahobo 2008).

According to Solway (2002), these concepts of 'inferior' and 'superior' are socially constructed based on specific historical, political and social circumstances. A superior group is that group which dominates by successfully controlling other groups through superior access to social power (Nyathi 2003). According to Tatum (2000:11-12), dominant groups are characterised by setting the parameters within which subordinate groups operate, holding power and authority in the society relative to the inferior or subordinate groups and having the greatest influence in determining who gets the best jobs and what language can be taught in schools and so on.
The San within this social fabric are considered to be among the 'inferior' groups and perhaps at the very lowest rung of this group, which means they are inferior to any other existing group. As expressed by Good (1999), they are a group below even other members of the unskilled working class or landless peasantry who are excluded from the affluence and participation variously enjoyed by most of the rest of the population. According to Nyathi (2003), the San even in an area occupied by them and one of the minority non-Tswana-speaking group are still considered the inferior by the other groups and as such their inferior status applies both nationally and locally.

\section{Theoretical framework}

\section{The theory and practice of participatory development and} decentralised planning

There are various theories that provide a strong justification for decentralised decision-making and the importance of local government, on the grounds of efficiency, accountability, manageability and autonomy (Shah 2006). However, in Botswana, the relationship between the central government and the local government appears to be anchored on two broad-based theories. The first theory propagated by Stigler quoted by Shah (2006) contends that the closer a representative government is to the people, the better it works and that people should have the right to vote for the kind and amount of public services they want. In the context of this paper, decentralisation is thus used to mean the transfer of authority to make some decisions and manage public affairs from the central government to the local level.

The above discussion implies that decision-making should occur at the lowest level of government consistent with the goal of allocative efficiency (Shah 2006). This view is also embedded within the participatory development principle of giving local communities a 'voice'. It is this 'voice' that leads to greater consciousness of abilities and possibilities of making a difference (Budiwiranto 2007). As such, with participatory development, a transformation of development practice is ensured by closing the gaps that have been causing social exclusion of the excluded groups (Hickey \& Mohan 2004). While participation in development is constructed in different ways, in the context of this discussion, it has been used to denote the engagement and involvement of people at the grassroots level in decision-making processes. However, analysis by Mwanzia and Strathdee (2010:4) has illuminated that one of the challenges with participatory development is that power is frequently delusional and conceals the extent to which participatory processes are manipulative and marginalising rather than liberating to disadvantaged people.

As explained by Cobbinah (2011:53), although participation can invite the ordinary citizens to the development decisionmaking table, sometimes it is disempowering as local people are just invited to meetings where they are meant to witness development decision-making taking place. Gaventa (2004) cautions that if power relations are ignored, participation evolves as underhanded disempowerment because many 
development programmes are thought to be participatory, but they are only participatory when the ideas of the oppressed are aligned to those of the oppressors.

Another theory underpinning decentralised planning is proposed by Oates (quoted by Shah 2006), which holds that services should be provided by the jurisdiction having control over the minimum geographic area that would internalise benefits and costs of such provisions because local governments understand the concerns of local residents. The theory posits that local decision-making needs to be responsive to the people for whom the services are intended and that this would encourage fiscal responsibility and efficiency. Thus, the notion of local government should be motivated by the desire for efficient delivery of services, participatory democracy in the sense of giving citizens multiple opportunities for political influence (Engel 1999) and accountability, among others.

Elsewhere it has been stated that the Government of Botswana's efforts in rural development included building effective institutions for the implementation of rural development programmes. In consequence, a process of decentralisation was embarked on to achieve this goal, hence the establishment of local government institutions. However, unlike in other countries, local government institutions in Botswana are not established by the national constitution. They merely derive their legitimacy and power to function from statutes or administrative directives and 'consequently they have no inherent competence derived from the constitution' (Hope 2000:519). Because they were merely established by Acts of Parliament, they can be abolished anytime at the discretion of the Legislature. This also implies that their spheres of operation are prescribed by the central government and could be varied from time to time, either by expanding or contracting their mandates or by increasing or decreasing financial and administrative support.

The Presidential Commission on the Local Government Structure captured this submission from VDCs to the effect that Land Boards did not recognise them as duly constituted institutions in the planning process because they were not creatures of statute (Republic of Botswana 2001a:71), noting that this negative attitude impacts badly VDCs' ability to carry out their mandates.

This arrangement means that local government, of which VDCs are a part, is simply an extension of the central government responsible for implementation of central government projects at the local level. This exposes local government to the caprices of the centre in that the centre determines the functions and scope of local government and retains the principal right to recall functions delegated to local government. The centre is legally empowered to broaden or narrow the functions of local government without consulting them. This arrangement has significant implications for the effective operation and sustainability of local government institutions and by extension of the implementation, management and coordination of rural development.

In similar ways, it has to be noted that the relationship between the central government and the local government is never static; hence, decentralisation should be understood as an evolving process in which the balance of power between the central government and local government institutions changes from time to time, often in the interest of the central government. At one point the central government may give some of its responsibilities to the local government institutions, while at other times the centre may recall such responsibilities. Nonetheless, as already stated, the argument for decentralisation largely identifies two key purposes that can be achieved for rural development by transferring decision-making powers to the local level institutions.

This section has discussed the theory and practice of participatory development in the context of giving underprivileged communities a voice. However, the discussion pointed out that because of unequal power relations, communities 'participate' to the extent that they merely give legitimacy to outsiders' development choices. The concept of decentralisation was discussed extensively to illuminate the complexity of power relations demonstrating that local governments, of which VDCs are a prominent part, are mere appendages of the central government.

\section{Village Development Committees as forums for community engagement}

As already discussed in the preceding section, the institutional framework of rural development covers all organisations that have a responsibility for planning and implementation of rural development programmes and projects. The framework comprises the national level institutions and local level structures situated in the districts and villages. At the village level, institutions of decentralisation include, among others, VDCs which are elected bodies responsible for planning and overseeing village development in respective villages. VDCs were established by a Presidential Directive of 1968 for the purpose of implementing development programmes in villages. A VDC is the main village institution responsible for all development matters. It is a village-level institution designated to ensure that grassroots development actually takes place through direct participation of citizens in decisions relating to the development of the village. The VDC coordinates all village institutions' activities such as those of Parents Teachers Association, Women's Organisations and other voluntary organisations. The VDC is responsible to the Kgotla ${ }^{1}$ on matters related to development. The functions of the VDC are the following:

(1) identify and discuss local needs

(2) help villagers to prioritise their local needs

(3) formulate proposals for the solution of identified local needs

1.A Kgotla is a traditional village assembly where issues of local and national importance are debated. 
(4) determine the extent to which the people can satisfy their identified needs on a self-help basis

(5) develop a plan of action for their village area

(6) solicit the assistance of donors and other development agencies

(7) mobilise the community and its institutions for development action

(9) provide a forum of contact between village leaders, politicians and district authorities to enhance the flow of development information

(10) represent villagers in development matters and to act as a source and referral point in matters pertaining to village development

(11) coordinate national activities in their respective villages.

A VDC includes 10 members elected at a Kotla meeting:

- There are five executive members and five additional members.

- Executive members are Chairperson, Vice-Chairperson, Secretary, Vice-Secretary and Treasurer.

- In addition, there are a number of ex-officio members (people who by virtue of their positions are automatically members of the VDC).

- These ex-officio members are Headmen, Councillors and Extension workers.

- $\quad$ They do not hold any of the executive offices.

- $\quad$ Further, there may be co-opted members (required to provide advice or some form of assistance).

The composition of VDCs itself raises eyebrows in that (the numbers of) duly elected members, that is, those who actually represent the community, may be outnumbered by ex-officio members in so far as it is required that extension workers stationed in villages should become members of the VDCs. This arrangement has the potential to inadvertently drown community's voice and make government views (through extension workers) dominant.

Essentially, VDCs have an important role to play in rural development, especially by promoting citizen participation in rural development activities. Yet, their effectiveness in facilitating people's participation in rural development remains questionable. This is in spite of the widely held view that 'since their formation, VDCs have played a major role in helping communities identify their needs and crystalize them for inclusion in the various district development plans' (Republic of Botswana 2001:68). For instance, the Presidential Commission on Local Government Structure noted that citizens appreciate that VDCs facilitate bottom-up planning in that they reach out to the smallest clusters of communities and in this manner identify requirements and development needs at village levels. The Commission nevertheless highlighted that VDCs did not realise their full potential because newly elected members were not given proper orientation regarding their roles and responsibilities (Republic of Botswana 2001:69). In addition, as already pointed out, it seems that VDCs are not taken seriously by other local government institutions on account of their not being creatures of statute.

The next section discusses the research design used for the study.

\section{Methodology}

This paper draws from a more comprehensive qualitative study undertaken among the San in Khwee and Sehunong settlements. As the study was intended to understand experiences and perceptions, qualitative research paradigm was found suitable because of its ability to allow for a detailed capture of experiences and perceptions as they evolve within their natural environment. Semi-structured interviews (interview guide) and focus group discussions were used to collect data. The use of these two data collection methods was considered to compensate for each method's individual limitations and strengthen their advantages as well (Shenton 2004). These two methods allowed for the collection of detailed data and stories that gave a detailed view of VDCs in Khwee and Sehunong.

The sample in each study area was made of seven participants. Participants were selected through purposive sampling and snowball sampling techniques. The sample consisted of three members of the VDC, councillors, chiefs and government community development extension officers such as Remote Area Development Programme (RADP) officers and school heads in each settlement. The participants were self-selecting because in their positions, they work with the community in development interventions and represent the community in development decision-making forums. It is important to note that in all the settlements, both community development workers and the councillors were from Tswana-speaking groups, thus non-San.

The data analysis followed the grounded theory data analysis procedures. NVivo software was used in the data analysis process.

\section{Findings and discussion Role of Village Development Committees}

Compelling evidence suggests that participants in this study recognise the VDC as an important body in facilitating development that addresses the felt needs of the local community. Most participants seem to believe that through the VDC platforms, the communities of Khwee and Sehunong will be empowered to play an active role in their community's collective development priorities. In emphasising the importance of empowering communities through involvement in decision-making, proponents of participatory development such as Chambers (1997) and Freire (1972) argue that the 'inferiors' and the oppressed should have a 'voice' in their development so that the process could address their felt needs and priorities in a meaningful manner. In this manner, it is believed that development interventions will be 
relevant and increase community ownership and commitment (Cobbinah 2011).

In all the focus group discussions, it was emphasised that if the VDC was allowed to execute its mandate as outlined elsewhere in this paper, the VDC would be playing an important role in local governance and decision-making, thus allowing local people to be in the driver's seat of their development and have a 'voice'. Sharing the same sentiments were the chiefs in both the villages who explained that if the VDC's functions are effectively discharged the community will be empowered to identify their development needs and find solutions to their own problems.

This view was also reiterated during individual interviews. For instance, in emphasising the importance of local people in solving their own problems, one participant (VLS 1) in Sehunong reiterated that:

'if things were run according to the book, as the VDC we would be doing so much better for our community because we are always here and we know the needs of our community.' (A youth female participant)

Also, one participant (VLK 2) in Khwee revealed that as the VDC in Khwee they have sound development ideas for their community but are constrained by lack of voice as most decisions about their community are made in a top-down manner. This view by participants shows that they recognise the agency of citizens as 'makers and shapers' rather than as 'users and choosers' of interventions designed by others (Gaventa 2004). It should be noted that it is not only the participants of this study that hold this view; a study by Seleka (2015) reiterated the same - the members of the VDC in Mankgodi are complaining of a top-down development approach which sidelines them as a community mouthpiece.

One of the participants (VLK 6) further observed that in Khwee, it appears that the VDC has only a ceremonial role of gracing occasions such as attending Kgotla meetings when a government minister is in the village. According to some participants in Sehunong, the only time the VDC is recognised and allowed to make a decision is when it comes to identifying a beneficiary for a house donation made by NGOs or private organisations. This is how they put it:

'As the VDC, we are usually involved when there is a house to be donated, that is when we are asked to choose someone who can be a beneficiary. Otherwise mostly we are just told about decisions that have been made.' (A middle aged female participant)

The above excerpt illuminates a critical issue that for a long time has clouded the literature on decentralisation and participatory development - the empowerment rhetoric of participation. There is evidence from the findings that confirms that despite the VDC being seen as a tool for decentralised decision-making to enhance participatory development, government officials and political office bearers continue to pay lip service to the VDC participatory processes (Ngwenya 2008). The findings suggest that the extent and the form of participation in decision-making by the VDC are determined by others. As such, even though the idea is to bring local governance to the local community, traditionally powerful stakeholders continue to hold onto power and mask by tokenism so that the local community and the VDC have pseudo-power experience and feel that they are involved.

Freire (1972) warns that the powerful give the powerless false power to gain their consent to cling to power. From a rightsbased perspective, if the VDC is excluded in this manner, it is an infringement on the community's rights to democracy. An implied rationale for participatory governance is that democracy is in essence an expression of popular sovereignty in which all members of the community are entitled to an equal say in public affairs (Friedman 2005). As such, government and other stakeholders in development need to not only recognise the right to participation only in terms of voting rights, but also through active participation in development policy and decision-making processes. This suggests that more widely the role of the VDC should be seen as pivotal to enhancing democracy and decision-making.

Denying the VDCs a share in decision-making does not only lead to the erosion of responsibility, it also alienates and undermines feelings of identity and self-worth. For the San, the dynamics involved are even more complex because of unequal ethnic relations that for a long time position them at the lowest on the social rung. This is further discussed in the following section.

\section{Power relations in development planning}

According to Foucault (1980), existing relations of power are part and parcel of every interaction because all social relations are power relations. Based on this, Fung and Wright (2001) have argued that power relations more often than not exclude certain actors and their views from the decision-making platforms, more especially where countervailing power is weak or non-existent. Considering the position of the San in the social hierarchy, the findings have suggested that the effectiveness of the VDC in Khwee and Sehunong is thwarted by several factors such as power relations between different stakeholders, among others. In the case of Khwee and Sehunong, the unequal power relations between stakeholders are mainly based on ethnic relations that underlie the Botswana society. As observed by one participant (VLS 4), the VDCs in Sehunong face challenges because their plans as the VDC are rarely taken into consideration by government because the San are just looked at as a group of no consequence, 'ke masarwa':

'Our decisions are not taken seriously because [we are] ke masarwa, a powerless group. People should initiate their own development because in that way, they will come up with things that they can commit to. Imagine, as the VDC we will suggest something and Government gives something else. There was a time when we were given pigs for a community income generation project, the VDC members ended up having to be the only ones involved with the project because the community 
distanced itself from the project as they never asked for a piggery project.' (A middle aged female participant)

This situation is often attributed to improper participatory practices. The community is sending a message that the project is irrelevant for them.

Some participants further gave examples of situations where the VDC would be invited to decision-making meetings and find out that decisions have already been made. This is evidenced in the deliberations made in the Khwee focus group as follows:

'Even at times when they say they involved us, you will find that they invite the chief, councillor and the VDC. When you get there, everything has been finalised about our own village, what's left is only to ask the VDC if the decision is good for the village. Not that if you say it is not, it will change anything at all. I am however doubtful if other villages are treated in this manner, I think for us being San, people just know that we can't take them to task.' (A youth male participant)

The above excerpts show that although government talks about giving power to the people, this is more rhetoric than practical - government still finds it difficult to relinquish decision-making power to communities. In fact, Cobbinah (2011:49) is concerned about how government bureaucrats can transfer power to the grassroots when they remain in control of financial resources. In relation to this, Kapoor (2005:1207) observed that 'pretending to step down from power and privilege, even as one exercises them as a master of ceremony, is reinforcement, not a diminishment of such power and privilege'. As such, the government as the main financer of national development and, by extension, VDC projects automatically places the community in the position of a 'beggar or recipient' while itself becoming the 'provider'. In effect, this relationship maintains the power at the top; if the VDC does not align its projects with those of the financer (government), their decisions and choices might be easily overlooked. As explained by Gaventa (2004), those development projects and programmes said to be participatory are only participatory when the ideas of the grassroots people are aligned to those of the financer. Scholars such as Mohan (2002) have warned that community participation has been reduced to administrative manipulation in which communities are only consulted. According to Mohan, participation as consultation is only used to maintain the status quo because it only allows the 'have-nots' to be heard, but without power to make sure that in the end their voice will be acted on by those with power.

Power dynamics has also been demonstrated in the way government service providers treat the VDCs in Khwee and Sehunong. Community Development/Remote Area Development Officers who are ex-officio members of the VDC have been accused of clinging to power and limiting the effectiveness of the VDC. As reflected in the Khwee focus group discussion, Community Development Officers are accused of prejudice in their service provision:
'Community Development Officers when they are working with people who are not San, they do not despise the tribe. As such, they put a lot of effort to help and guide the VDC. For us, they know that we can't demand accountability because we are just powerless. So they don't exert themselves enough.' (A youth male participant)

The same sentiments about the Community Development/ RADP Officers were shared by participant VLS 4 who explained that:

'VDCs in areas predominantly occupied by the San are ineffective because community development workers despise San people as they are from the Tswana speaking groups. You will realise that VDCs in Mmea, Xere and Kedia are as ineffective as the Khwee VDC because [of] ke masarwa. But look at those VDCs where it's Batswana, the VDCs there are very successful, they have houses and other projects that improve the community life.' (A youth male participant)

It should be noted that the Community Development/RADP Officer as an ex-officio member of the VDC is charged with the responsibility of guiding the VDC and providing them with information on which to base deliberations. Based on this, the Community Development/RADP Officers should help create a conducive environment where the San can engage in the development process informed. However, based on the findings, it appears that the Community Development/RADP Officers do not play their role effectively, which in turn makes the VDC less effective. Participation rests on the assumption that people can make intelligent and well-informed decisions and actions (Fetterman 2005:10). Therefore, if those that are supposed to train and guide the VDC are not willingly doing their job, it means the VDC will operate in the dark.

The findings suggest that power relations do not only exist between the VDC and government officials but it is also evident among the VDC and the political office bearers such as local councillors who are also ex-officio members. According to some participants, 'Basarwa are not listened to, so even when the VDC state its priorities, at the end of the day, no one listens' (VLS 2). This issue was also reiterated in the focus groups. Participants in the Khwee focus group observed that their councillor is non-San and it appears he despises the San people:

'Things are not going well here just because it is a place occupied by the San people, who are without a name in Botswana. When you look at the VDCs in places occupied by non-San you will see a big difference in the way people are engaged. Imagine, our councillor can just go for a full council meeting without holding a meeting with us. We ask ourselves, what is it that he is going to present when he did not consult us. This is done because we are Basarwa, we don't have rights.' (A middle aged male participant)

The same was discussed in the Sehunong focus group:

'Since our councillor is not a Mosarwa, they think because we are Basarwa there is no need to consult us. Development should start from the people who need it. You should not think for them, you should hear from them. If you do not get it from them, it means 
that whatever you are bringing is yours not theirs. You should engage them to know what they want, but for us here it's a different story because they just say ke masarwa.' (An elderly male participant)

A key issue that can be picked up from the above excerpts is that social relations are indeed power relations and those who are privileged by virtue of their social status will hold power over the underprivileged. In that case, even government officials tasked with the responsibility to facilitate the empowerment of the less privileged may not be motivated to involve those who are considered inferior, particularly minorities.

\section{Conclusion}

This paper has shown that while VDCs have been identified as village-level institutions with the responsibility to facilitate genuine community participation, in reality the central government uses its financial muscle to impose its own development agenda. The central government often does so by declining to fund projects identified and prioritised by local communities. On the other hand, unequal power relations based on ethnicity seem to affect the manner in which the VDC should be operating. In effect, VDCs merely exist to legitimise the top-down approach as opposed to the bottom-up approach where development interventions are decided for local communities by outsiders precisely on the grounds of unequal power relations. Consequently, the hopes of VDCs have been dashed owing to this power play. Therefore, the VDCs are not seen as effective organs for facilitating active participation of communities in the development process in the country. The paper thus recommends that the Government of Botswana as the main stakeholder in national development including the development of San communities should commit to genuine community participation. On the other hand, the San should be capacitated to be able to demand genuine participation and challenge all the structures that disempower them to genuinely participate in their own development.

\section{Acknowledgements}

This research was supported by the University of Botswana. The authors would also like to extend their gratitude to the research participants in the two settlements.

\section{Competing interests}

The authors declare that they have no financial or personal relationships which may have inappropriately influenced them in writing this article.

\section{Authors' contributions}

K.M-F. worked on the first half of the article while K.D. worked on the second half. K.M.F. was the research leader and worked on much of data analysis and interpretation. K.D. was responsible for the conceptual contributions, literature search and review.

\section{References}

Budiwiranto, B., 2007, 'Pesantren and participatory development in Indonesia', Master's thesis, Australian National University, Canberra.

Chambers, R., 1997, Whose reality counts? Putting the first last, ITDG Publishing, London.

Cobbinah, J.E., 2011, 'Barriers in community participation and rural development', PhD thesis, University of Bradford.

Datta, A. \& Murray, K., 1989, 'The rights of minorities and subject peoples in Botswana', in J.D. Holm \& P.P. Molutsi (eds.), Democracy in Botswana, Macmillan, Gaborone, 58-74.

Dipholo, K. \& Mothusi, B., 2005, 'Decentralization in Botswana: The reluctant approach', Journal of Social Development in Africa 20(1), 40-58. https://doi. org/10.4314/jsda.v20i1.23893

Ditshwanelo, 2003, 34th Session of the African Commission of Human and Peoples' Rights. November 10, 2003, Gambia. Banjul, Item 9: Human Rights Situation in Africa [Press release].

Engel, M., 1999, State \& local government: Fundamentals \& perspectives, Peter Lang, New York.

Fetterman, D.M., 2005, 'Conceptualizing empowerment in terms of sequential time and social space', in D.M. Fetterman \& A. Wandersman (eds.), Empowerment Evaluation Principles in Practice, Guilford Press, New York, 209-214.

Foucault, M., 1980, Power/knowledge: Selected interviews and other writings, Harvester Wheatsheaf, Brighton.

Freire, P., 1972, Pedagogy of the oppressed, Penguin, Harmondsworth.

Friedman, S., 2005, 'On whose terms? Participatory governance and citizen action in post-apartheid South Africa', Paper for International Institute of Labour Studies Workshop, 9-10 December, Geneva, Switzerland.

Fung, A. \& Wright, E., 2001, 'Deepening democracy: Innovations in empowered participatory governance', Politics and Society 29, 5-41. https://doi.org/10.1177/ 0032329201029001002

Gaventa, J., 2004, 'Towards participatory governance: Assessing the transformative possibilities', in S. Hickey \& G. Mohan (eds.), Participation: From tyranny to transformation? Exploring new approaches to participation in development, Zed Books, London, 25-42.

Good, K., 1999, 'The state and extreme poverty in Botswana: The San and destitutes', Journal of Modern African Studies 37(2), 185-205. https://doi.org/10.1017/ S0022278X99003043

Hickey, S. \& Mohan, G., 2004, 'Towards participation as transformation: Critical themes and challenges', in S. Hickey \& G. Mohan (eds.), Participation from tyranny to transformation? Exploring new approaches to participation in development, ZED Books, London, 3-24.

Hope, K.R., 2000, 'Decentralization and local governance theory and the practice in Botswana', Development Southern Africa 17(4), 519-534.

Kapoor, I., 2005, 'Participatory development, complicity and desire', Third World Quarterly 26(8), 1203-1220. https://doi.org/10.1080/01436590500336849

Mohan, G., 2002, 'Participatory development', in V. Desai \& R.B. Potter (eds.) The companion to development studies, Arnold, London, 49-54.

Mwanzia, J.S. \& Strathdee, R.C., 2010, Participatory development in Kenya, Ashgate Publishing Limited, Surrey.

Ngwenya, B.N., 2008, Local institutions and democratization of development in Botswana: A case study of village development committees in Ngamiland, Bay Publishing, Gaborone.

Nyathi, M.D., 2003, Social exclusion as a barrier to poverty reduction: The case of Basarwa in Botswana, University of Natal, Durban.

Nyathi-Ramahobo, L., 2008, Minority tribes in Botswana: The politics of recognition, viewed 23 July 2017, from www.minorityrights.org

Reddy, P.S., 1999, 'Local government restructuring in South Africa', in P.S. Reddy (ed.) Readings in local government management and development: A Southern African perspective, Junta and Company, Cape Town, 49-64.

Republic of Botswana, 2001a, Report of the second presidential commission on the local government structure in Botswana, Government Printer, Gaborone.

Republic of Botswana, 2001b, Village/ward development committee guidelines, Government Printer, Ministry of Local Government, Gaborone.

Republic of Botswana, 2002, Revised national policy for rural development, Government Printer, Gaborone.

Saugestad, S., 2001, The inconvenient indigenous: Remote area dwellers in Botswana donor assistance and the first people of the Kalahari, The Nordic African Institute, Sweden, Uppsala.

Seleka, M., 2015, 'Participation and rural development in contemporary Botswana: Rhetoric or reality? The case of Mmankgodi Village', A dissertation in Partial Fulfillment for the Degree of Masters of Arts in Development Studies, University of Botswana.

Shah, A. (ed.), 2006, Local governance in developing countries, World Bank, Washington, DC. 
Sharma, K., 1999, 'Decentralisation for democratisation and strengthening of local government', in P.S. Reddy (ed.) Local government democratization and decentralization: A review of the Southern African region, Junta Publishers, Kenwyn.

Shenton, A.K., 2004, 'Strategies for ensuring trustworthiness in qualitative research projects', Education for Information 22, 63-75. https://doi.org/10.3233/EFI-200422201
Solway, J., 2002, 'Navigating the "neutral" state: Minority rights in Botswana', Journal of Sothern African Studies 28(4), 711-729. https://doi.org/10.1080/0305707022 000043485

Wagner, R.W., 2006, 'An endless desert walk: Perspectives of education from the San in Botswana', International Journal of Educational Development, 26(1), 88-97. https://doi.org/10.1016/j.ijedudev.2005.07.014 